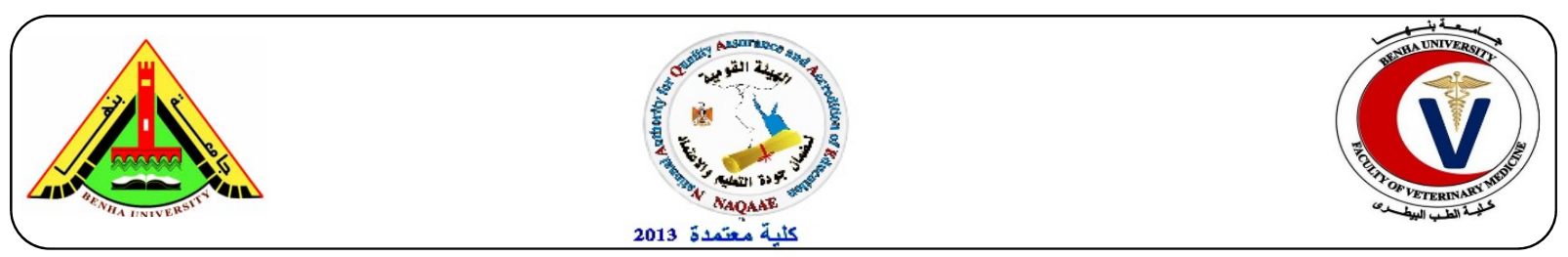

\title{
Detection of aflatoxins, ochratoxins and some chemical adulterants in raw Milk
}

\author{
Ola, F. A. Talkhan*, Flourage M. Rady*, * , Eman, F. Mohamed* \\ ${ }^{*}$ Animal Health Research Institute, Egypt \\ ${ }^{* *}$ Faculty of Applied Medical Science- Shaqra University
}

\begin{abstract}
A B S T R A C T
Milk is essential for the nourishment of children and adult life providing their daily food requirements. Aflatoxins are mycotoxins have been produced by some species of Aspergillus. Ingested Aflatoxins B1 (AFB1) are metabolised into carcinogenic Aflatoxins M1 (AFM1) which are eliminated through milk. Also, seller and producer add chemical substances (adulterants) to milk to increase its shelf life. Adulteration is defined as removal or replacement of milk components and an addition of substances without a consumer's knowledge which is banned. The presence of mycotoxins or chemical adulterants has serious health risk. The present study evaluated 60 samples of cow's raw milk in El- Minufia governorate for the presence of aflatoxins, ochratoxins and some chemical adulterants. Also, its chemical composition (fat, S.N.F and protein). The result indicated that $16.7 \%, 8.33 \%$ of tested samples contained aflatoxins M1 and aflatoxins M2 respectively. All the tested samples were free from ochratoxins. Also, 88.33\% of collected milk samples contained different chemical adulterants; inhibitory substances (70\%), formalin (41.67\%), water (37.5\%), hydrogen peroxide (20\%), boric acid (16.70\%), carbonate and bicarbonate (8.30\%), nitrate (5\%). Moreover, $50 \%$ and $54.17 \%$ of milk samples were less than the legal requirement for fat and S.N.F respectively; then protein was decreased in $41.67 \%$ of samples. The present study recommended to monitor the marketing of milk by instructions and rules, which include the standards of the sold milk and to control the milk quality to be safe for the consumer.
\end{abstract}

Keywords: milk, aflatoxins, ochratoxins, chemical adulterants, Minufia.

(http://www.bvmj.bu.edu.eg)

(BVMJ-31(2): 283 -288, 2017)

\section{INTRODUCTION}

Milk as a natural product is a complete food and can supply infants and adult with the daily requirement of nutrition. Mycotoxins are toxic substances produced by moulds that growing on agricultural products; some have mutagenic or carcinogenic effects, others are toxic for specific organs, and others have health risks (Bezerra da Rocha et al., 2014). Aflatoxin, ochratoxin, fumonisin, T-2 toxin, vomitoxin, and zearalenone are mycotoxins that have the most attention by industry and academic research (Chi and Broomhead, 2009). Aflatoxins produced by some species of Aspergillus that have hepatotoxic, mutagenic and carcinogenic effect (Bennett and Klich, 2003). Dairy cows are sensitive to aflatoxin as young animals; not for the toxicity of AFB1 to the cow but because of the resulting AFM1 in the milk as AFB1 is metabolised into carcinogenic AFM1 which is eliminated through milk (Chi and Broomhead, 2009) and have a risk for consumer health. Aflatoxin M1 is a probable human hepatocarcinogen found in the milk of animals that consume feeds contaminated with aflatoxin B1
(AFB1) which produced by fungi of genus Aspergillus (Sacca et al., 2007). Indeed, untreated mycotoxin contaminated feeds fed to dairy cattle may reduce milk production, alter milk compositions, or produce toxins in milk (Chi and Broomhead, 2009). On the other hand, Ochratoxins (OTA) A and B are produced by several fungal species, even though only low concentrations of OTA may have existed in milk, these small amounts may be important to consumers of large quantities of this product, particularly children (Skaug, 1999). On the other hand, milk considered as a good environment for bacteria and can be changed. So, sellers and producers add some chemicals to delay this change without awareness its health risk; to increase income and to mask these added chemicals. Undoubtedly all these make changes to the milk nature and known as adulterants which had been reported in different countries (Embrapa, 2014). Water, whey, sucrose, starch, salt, sodium hydroxide and formaldehyde are substances used for milk adulteration (Bansal and Singhal, 1991; Santos et al., 2013). Also, 
sodium Citrate, sodium hydroxide, sodium chloride, sucrose, phosphates, carbonates, bicarbonates and hydrogen peroxide were used to correct milk defects, such as high acidity and microbial growth, and to increase its volume (Hoorfar J., 2012). Using of urea and formaldehyde to cover water addition to milk was reported (UOL, 2014). Milk adulteration is banned owing to its hazard effect on health (Beall and Scofield, 1995). Therefore, this study was undertaken to evaluate the presence of aflatoxins, ochratoxins and some chemical adulterants in cow's milk and its chemical composition.

\section{MATERIAL AND METHODS}

\subsection{Collection of samples}

A total of 60 random samples of fresh raw milk were collected from supermarkets and dairy milk shops from El- Minufia Governorate. The fresh raw milk was collected and transferred into an ice box to the laboratory directly without undue delay to be immediately examined for detection of aflatoxins and ochratoxins, chemical adulterants and chemical composition.

\subsection{Quantitative estimation of mycotoxins}

\subsubsection{Aflatoxins}

The presence of aflatoxin M1 and M2 were detected in samples by HPLC after post-column derivatization with the electrochemical generation of bromine (KOBRA cell - Rhone diagnostic technologies, UK) with a current of $100 \mu \mathrm{A}$ and a fluorescence detector (Shimadzu LC-10 AD Model; $360 \mathrm{~nm}$ excitation wavelength; $435 \mathrm{~mm}$ emission wavelength; with Shim-Pack CLC - ODS column, $5 \mu \mathrm{m}, 4.6 \times 250 \mathrm{~mm}$, preceded by a guard column Shim - Pack G - ODS, $5 \mu \mathrm{m}, 4 \times 10 \mathrm{~mm}$ ). The mobile phase was deionized wateracetonitrile-methanol $(60: 20: 20, \mathrm{v} / \mathrm{v} / \mathrm{v})$ with the addition of $350 \mu \mathrm{L}$ of $4 \mathrm{M} \mathrm{HNO} 3$ and $120 \mathrm{mg}$ of $\mathrm{K}$ $\mathrm{Br}$ at a flow rate of $1 \mathrm{ml} / \mathrm{min}$. The injection volume was $50 \mu \mathrm{l}$. The quantification of aflatoxin was performed by measuring its peak areas at each retention time and comparing it with the calibration curve (Galvano et al., 2001). The performance of the method, aflatoxin recovery and effectiveness of the clean-up procedure, was evaluated by the samples spiked with the aflatoxin.

\subsubsection{Ochratoxins}

The samples were extracted according to the method as described by Iqbal et al. (2013) with few modifications. The sample $15 \mathrm{ml}$ was blended ( 15 $\mathrm{min})$ in $50 \mathrm{ml}$ of acetonitrile - water $(45: 05, \mathrm{v} / \mathrm{v})$, using high speed blending and then the extract was filtered through filter paper. About $5 \mathrm{ml}$ of the filtrate was mixed with $50 \mathrm{ml}$ of phosphate buffer saline (PBS) and filtered through a glass microfiber. Then $10 \mathrm{ml}$ of the filtrate was passed through immunoaffinity columns. OTA was eluted from the column by passing $1.5 \mathrm{ml}$ of methanol (HPLC grade) and collected in a vial. The eluate was evaporated until dryness at $40^{\circ} \mathrm{C}$ and residues were re-dissolved in $1 \mathrm{ml}$ of mobile phase i.e. acetonitrile: water: acetic acid $(47 / 51 / 2, \mathrm{v} / \mathrm{v} / \mathrm{v})$ for HPLC analysis. Calibration standards were prepared by combining standard solutions into the neat solvent and blank matrix extracts (matrixmatching) to yield the desired concentrations in the range of $10-500 \mu \mathrm{g} / \mathrm{L}$ for each analyte.

\subsection{Detection of inhibitory substances}

Qualitative B. subtilis disc assay method (American Public Health Association "APHA", 1992) was used as follow: Each milk sample was heated at $80^{\circ} \mathrm{C}$ for $5 \mathrm{~min}$ to inactivate the naturally occurring inhibitory substance in milk and to eliminate the possibility of false-positive results. After cooling, $0.1 \mathrm{ml}$ of each milk sample was applied in a circular well in Bacto-Pm indicator agar inoculated with $B$. subtilis organism. The plates were examined for violet coloured inhibition zones after 2.5-3.0 hours' incubation at $65^{\circ} \mathrm{C}$. The presence of inhibition zone was recorded as a positive result.

\subsection{Chemical adulterants}

\subsubsection{Detection of preservatives}

Formalin, Hydrogen peroxide, Salicylic acid, Boric acid, carbonate \& bicarbonate, starch and nitrate were detected according to Draaiyer et al. (2009).

\subsubsection{Detection of urea}

The classical spectrophotometric method recommended by Bector et al. (1998) was applied.

\subsection{Chemical composition}

Analysis of milk for determination of its fat, solid not fat (S.N.F) and protein, was performed according to the techniques recommended by FSSAI (2015).

\section{RESULT}

\subsection{Prevalence of aflatoxins and ochratoxins in milk}

Table (1) revealed that 10 samples were positive for AFM1 with a range of $0.021-0.095(\mu \mathrm{g} / \mathrm{kg})$ and 5 samples were positive for AFM2 with a range 
of $0.010-0.034(\mu \mathrm{g} / \mathrm{kg})$. meanwhile, ochratoxins were nil for all samples.

\subsection{Chemical adulterants}

Figure 1 showed that inhibitory substances were present in $70 \%$ of milk samples. The prevalence of formalin was $41.67 \%$ followed by water $37.5 \%$ then hydrogen peroxide with $20 \%$, then boric acid $16.70 \%$, after that carbonate and bicarbonate came with $8.30 \%$, finally nitrate with $5 \%$. Meanwhile, starch, urea and salicylic acid were not detected.

\subsection{Chemical composition}

Table 2 and 3 showed that $50 \%$ and $54.17 \%$ of samples were below the Egyptian Standards (2005) for fat and S.N.F respectively. Protein ranged from $2.5 \%$ to $3.4 \%$ with average of $2.9 \%$

Table 1: prevalence of aflatoxins and ochratoxins in milk samples

$$
\text { Aflatoxins }(\mu \mathrm{g} / \mathrm{kg}) \quad \text { Ochratoxins }(\mu \mathrm{g} / \mathrm{kg})
$$

M1 M2

10 samples were positive with 5 samples were positive with $8.33 \%$

$16.7 \%$ and ranged from 0.021 and ranged from $0.010-0.034(\mu \mathrm{g} / \mathrm{kg})$

$-0.095(\mu \mathrm{g} / \mathrm{kg})$

Figure 1: chemical adulterants in milk samples

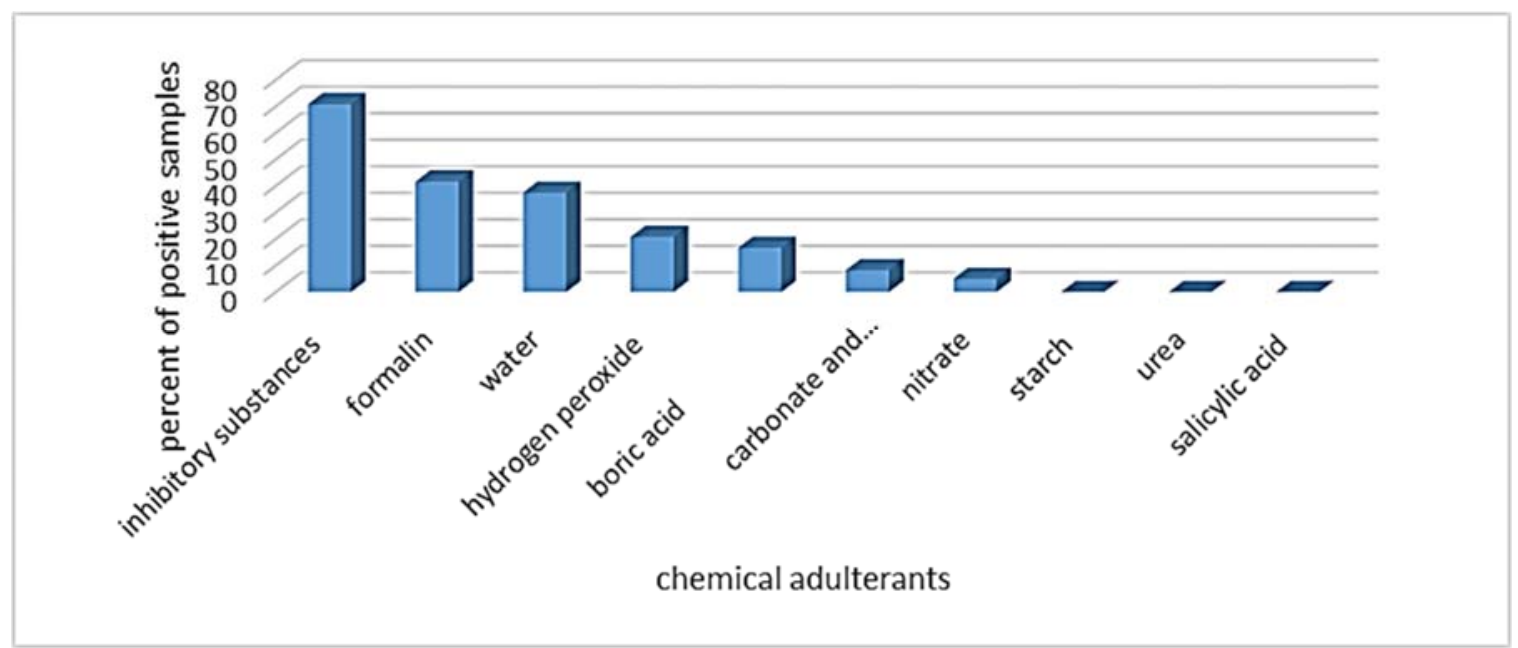

Chemical adulterants in milk samples: values as a mean $(n=60)$.

Table 2: chemical composition of milk sample

\begin{tabular}{llll}
\hline \multicolumn{1}{c}{ Range } & Minimum & Maximum & Average \\
Parameters & & & \\
\hline Fat $\%$ & 2.6 & 3.5 & 3.00 \\
S.N.F \% & 7.82 & 8.53 & 8.21 \\
Protein \% & 2.5 & 3.4 & 2.90 \\
\hline
\end{tabular}

Table 3: milk sample below legal requirement for fat $\%$, S.N.F $\%$ and protein $\%$

\begin{tabular}{|c|c|c|}
\hline Fat $\%$ & S.N.F\% & Protein \% \\
\hline $\begin{array}{l}\text { Fat } \% \text { for } 50 \% \text { of samples }< \\
3 \% *\end{array}$ & $\begin{array}{l}\text { S.N.F\% for } 54.17 \% \text { of samples } \\
\qquad<8.25^{*}\end{array}$ & $\begin{array}{c}\text { Protein } \% \text { for } 41.67 \% \text { of } \\
\text { samples } \leq 2.90\end{array}$ \\
\hline
\end{tabular}

* Egyptian regulated standards 


\section{DISCUSSION}

In the present study, our result data in table 1 revealed that $16.7 \%$ and $8.33 \%$ of collected samples contaminated with AFM1 and AFM2, respectively with a range of $0.021-0.095(\mu \mathrm{g} / \mathrm{kg})$ for AFM1 and 0.010- $0.034(\mu \mathrm{g} / \mathrm{kg})$ for AFM2 respectively. According to European commission regulation (2006), the MRL for AFM1 in milk is $0.05(\mu \mathrm{g} / \mathrm{kg}), 8.4 \%$ of samples exceed the established limit of EC, which come in accordance with Rouhi et al. (2015) and Jawaid et al. (2015) who stated contamination of milk samples with AFM1 that exceeded than standard levels established by United States regulation. On the other hand, Elzupir and Elhussein (2010) found that the percentage of AFM1 contamination in milk is $95.45 \%$ and also Nemati et al. (2010) who stated that all of the milk samples $(100 \%)$, were contaminated with AFM1. The aflatoxins production in grains is mostly influenced by harvest time; fertilization; irrigation; pest control; silage moisture; and storage practices. Therefore, the incidence and occurrence of AFM1 contamination in milk and dairy products depend on the country of origin (Prandini et al., 2009). The risk of AFM1 for human makes aflatoxin in dairy feed a constant concern as the concentration of AFM1 in milk is extremely dependent upon the dietary content of aflatoxin (Chi and Broomhead, 2009).

Figure (1) showed that $70 \%$ milk samples contained inhibitory substances. The presence of inhibitory substances as antibiotics, or antibiotic residues in the milk; because of their usage for prevention or treatment of various diseases of a bacterial cause (Petrovic et al., 2008). Noncompliance for period of antibiotic excretion (Kirbiš, 2006) the overdose of antibiotics, use of antibiotics that are banned or addition of antibiotics in milk in order to prevent multiplication of microorganisms, are the common cause of the presence of antibiotic residues in milk (McEwen et al., 1992; Nikolic et al., 2011). Either the producer or seller adds formalin, hydrogen peroxide, boric as a preservative to the milk for increasing its shelf life (Abbas et al., 2013). Formalin was the highest preservative used in our data. determination of formalin in milk samples was revealed (Abbas et al., 2013; Chanda et al., 2012). Formaldehyde decreased serum/tissue total antioxidant levels and it increased total oxidant level, oxidant and apoptosis index in the cell. Moreover, damages of liver and lung tissues and increasing of total oxidant capacity by formalin was stated (Aydin et al., 2015). While, Hydrogen peroxide followed formalin as preservatives. Hydrogen peroxide added to milk to delay microbial growth (Hoorfar J., 2012). Hydrogen peroxide adulteration disturbs the antioxidants activity in the body that causes a disturbance in natural immunity, which leads to increase ageing (Clare et al., 2003). On the other hand, boric acid is the least preservative used. Abbas et al. (2013) revealed the using of boric as for milk adulteration. Also, carbonate and bicarbonate were added to adulterated milk for neutralizing the developed acidity resulting from adulteration (Hoorfar J., 2012). Our result revealed the addition of carbonate and bicarbonate to adulterated milk. Adulteration of milk with carbonate was stated by Sanjeevani et al. (2011), Chanda et al. (2012) and Abbas et al. (2013). Gastrointestinal problems like gastric ulcer, colon ulcer, diarrhoea, and electrolytes disturbance may be caused by carbonates in milk (Beall and Scofield, 1995). Nitrates as oxidizing agents were used as preservative in milk ((Kamthania et al., 2014), our reported data in figure 1 revealed presence of nitrate in 5\% of samples. Foods contain nitrate and nitrite may be considered hazardous after ingestion in the gastrointestinal tract as they react with naturally occurred secondary amines to form potentially carcinogenic nitrosamines (Chamandust et al., 2016).

Table 2 and 3 showed that fat content of cow's milk samples ranged from $2.6 \%$ to $3.5 \%$ with an average of $3.00 \%$ and $50 \%$ of samples fat content were below the legal requirement of the Egyptian Standards (2005) for cow's milk (not less than 3\%). Adulteration of milk by partial skimming or addition of water lower its fat (Eman et al., 2015). Meanwhile, milk solids ranged from $7.82 \%$ to $8.53 \%$ with an average of $8.21 \%$ and $54.17 \%$ of samples, and were below the legal requirement of the Egyptian standard for cow's milk (not less than $8.25 \%$ ). The lower S.N.F content could be attributed mainly to adulteration by the addition of water (Harding, 1995) as it decreases only by the addition of water and not affected by partial skimming (Eman et al., 2015).

Our result in figure 1 revealed that $37.5 \%$ of samples were adulterated with water. Adulteration of milk with the water was stated by Ramya et al. (2016). On the other hand, Cow's milk protein ranged from $2.98 \%$ to $3.87 \%$ (Mahmood and Usman, 2010) and data in table 2 and 3 showed that $41.67 \%$ of examined samples decreased in their protein content. Milk Adulteration with water decreases its protein content as the S.N.F \% decreased along with protein \% (Kartheek et al., 2011).

\section{CONCLUSION}


The present study concluded that the collected milk samples contained aflatoxins but were free from ochratoxins. Moreover, some chemical adulterants were added to milk; all of them have a health risk. So, it is an obligatory to introduce regular systematic control of inhibitory substances and other adulterants in raw milk. Moreover, to Monitor the mycotoxin in animal feed.

\section{REFERENCES}

Abbas, N.M., Khattak, B., Sajid, A., Islam, T., Jamal, Q., Munir, S., 2013. Biochemical and bacteriological analysis of cows' milk samples collected from district Peshawar. Int. J. Pharm. Sci. Rev. Res. 21, 221-226.

American Public Health Association "APHA", 1992. Standard methods for the Examination of Dairy Products, 16th ed. Amer. Publ. Health Associat., Washington, D.C.

Aydin, S., Ogeturk, M., Kuloglu, T., Kavakli, A., Aydin, S., 2015. Effect of carnosine supplementation on apoptosis and irisin, total oxidant and antioxidants levels in the serum, liver and lung tissues in rats exposed to formaldehyde inhalation. Peptides 64, 1423.

Bansal, A., Singhal, O.P., 1991. Preservation of milk samples with formalin- Effect on Acidity. Indian Journal of Dairy Sciences 44 573.

Beall, D.P., Scofield, R.H., 1995. Milk-Alkali Syndrome-Associated with CalciumCarbonate Consumption - Report of 7 Patients with Parathyroid-Hormone Levels and an Estimate of Prevalence among Patients Hospitalized with Hypercalcemia. Medicine 74, 89-96.

Bector, B.S., Ram, M., Singhal, O.P., 1998. Rapid platform test for the detection of added urea in milk. Indian Dairyman 50, 59-62.

Bennett, J.W., Klich, M., 2003. Mycotoxins. Clin Microbiol Rev 16, 497-516.

Bezerra da Rocha, M.E., Freire, F.O., Maia, F.F., Guedes, M.I., Rondina, D., 2014. Mycotoxins and their effects on human and animal health. Food Control 36, 159-165.

Chamandust, S., Mehrasebi, M.R., Kamali, K., Solgi, R., Taran, J., Nazari, F., Hosseini, M.J., 2016. Simultaneous Determination of Nitrite and Nitrate in Milk Samples by Ion Chromatography Method and Estimation of Dietary Intake. International Journal of Food Properties 19, 1983-1993.

Chanda, T., Debnath, G.K., Hossain, M.E., Islam, M.A., Begum, M.K., 2012. Adulteration of raw milk in the rural areas of Barisal district of Bangladesh. Bang. J. Anim. Sci. 41, 112115.

Chi, F., Broomhead, J., 2009. Mycotoxins and Dairy Cattle: A Review for Dairy Producers. Oil-Dri Corporation of America $410 \mathrm{~N}$. Michigan Avenue, Suite 400 Chicago, Illinois 60611.

Clare, D.A., Catignani, G.L., Swaisgood, H.E., 2003. Biodefence properties of milk: The role of antimicrobial proteins and peptides. Current pharmaceutical design 9, 12391255.

Draaiyer, J., Dugdill, B., Bennett, A., Mounsey, J., 2009. Milk Testing and Payment Systems Resource Book: a practical guide to assist milk producer groups. FAO, Rome, Italy.

Egyptian Standards, 2005. Raw Milk Egyptian For Standardization. No. 154/2005.

Elzupir, A.O., Elhussein, A.M., 2010. Determination of aflatoxin M1 in dairy cattle milk in Khartoum State, Sudan. Food Control 21, 945-946.

Eman, S.M., Abd-Ellah, A.A., Elaref, M.Y., 2015. Detection of raw buffalo's milk adulteration in sohag governorate. Assiut Vet. Med. J. 61, $38-45$.

Embrapa, 2014. Estatísticas de produção de leite (Statistics of milk production). Brasília: Brazilian Agriculture Research Corporation. Available in $<$ http://www.cnpgl.embrapa.br/nova/inform acoes/estatisticas/producao/producao.php>. Accessed in June 2014

European commission regulation, 2006. (EC) no. 1881, Setting maximum levels for certain contaminants in foodstuffs. Official journal of the European Union, L 364, 5-24.

FSSAI, 2015. Food Safety and Standards Authority of India Ministry of Health and family welfare Government of India. Manual of Methods of Analysis of Foods. Lab. Manual I, Milk and Milk Products. Ministry of Health and Welfare. FDA Bhawan, Kotla Road, New Delhi-110002, India.

Galvano, F., Galofaro, V., Ritieni, A., Bognanno, M., De Angelis, A., Galvano, G., 2001. Survey of the occurrence of aflatoxin M1 in dairy products marketed in Italy: second year of observation. Food Addit Contam 18, 644-646.

Harding, F., 1995. Milk Quality. 1st Ed. Blackie Academic and Professional. Chapman and Hall, New York, London, Tokyo, Madras.

Hoorfar J., 2012. Case Studies in Food Safety and Authenticity: Lessons from Real-Life 
Situations, 1st ed, Cambridge: Woodhead Publishing Limited.

Iqbal, S.Z., Asi, M.R., Zuber, M., Akhtar, J., Saif, M.J., 2013. Natural occurrence of aflatoxins and ochratoxin A in commercial chilli and chilli sauce samples. Food Control 30, 621625.

Jawaid, S., Tapur, F.N., Nizamani, S.M., Afridi, H.I., 2015. contamination profile of aflatoxin M1 residues in milk supply chain of Sindh, Pakistan. Toxicology Reports 2, 1418-1422.

Kamthania, M., Saxena, J., Saxena, K., Sharma, D.K., 2014. Milk Adultration: Methods of Detection \&Remedial Measures. National Conference on Synergetic Trends in engineering and Technology (STET-2014). International Journal of Engineering and Technical Research.

Kartheek, M., Smith, A.A., Muthu, A.K., Manavalan, R., 2011. Determination of adulterants in food: a review. Journal of Chemistry Pharmacy and Research 3, 629636.

Kirbiš, A., 2006. Microbiological 5-plate screening method for detection of tetracyclins, aminoglycosides, cephalosporins and macrolides in milk. Slov Vet Res 43, 161168.

Mahmood, A., Usman, S., 2010. A Comparative Study on the Physicochemical Parameters of Milk Samples Collected from Buffalo, Cow, Goat and Sheep of Gujrat, Pakistan. Pak. J. Nutr. 9, 1192-1197.

McEwen, S.A., Black, W.D., Meek, A.H., 1992. Antibiotic residues (bacterial inhibitory substances) in the milk of cows treated under label and extra-label conditions. Can Vet J 33, 527-534.

Nemati, M., Mehran, M.A., Hamed, P.K., Masoud, A., 2010. A survey on the occurrence of aflatoxin M1 in milk samples in Ardabil, Iran. Food Control 21, 1022-1024.

Nikolic, N., Mirecki, S., Blagojevic, M., 2011. Presence of inhibitory substances in raw milk in the area of Montenegro. Mljekarstvo 61, 182-187.
Petrovic, J.M., Katic, V.R., Bugarski, D.D., 2008. Comparative Examination of the Analysis of beta-Lactam Antibiotic Residues in Milk by Enzyme, Receptor-Enzyme, and Inhibition Procedures. Food Analytical Methods 1, 119-125.

Prandini, A., Tansini, G., Sigolo, S., Filippi, L., Laporta, M., Piva, G., 2009. On the occurrence of aflatoxin M1 in milk and dairy products. Food Chem Toxicol 47, 984-991.

Ramya, P., Babu, A.J., Reddy, E.T., Reddy, Y.R., Rao, L.V., 2016. Analysis of various physico chemical properties of raw buffalo milk samples marketed in and around Proddatur town, YSR Kadapa district, Andhra Pradesh, India. Journal of Livestock Science 7, 30-34.

Rouhi, R., Kazemi, A., Jahromi A. S., Zabetian, H., Hossien, H., Yusefi, A., Madani, A., 2015. Levels of Aflatoxin M1 in Different Types of Milk Collected in Jahrom, Iran, WinterSpring 2013. American Journal of Animal and Veterinary Sciences 10, 193-196.

Sacca, E., Vallati, A., Ruatti, T., Bigaran, F., Piasentier, E., 2007. Aflatoxin occurrence in goat milk and supplied concentrate feed in farms of Veneto, Trentino and Friuli Venezia Giulia. Italian Journal of Animal Science 6, 632-632.

Sanjeevani, B.W., Chavan, B.R., Menkudale, G.V., 2011. Survey on adulteration of the milk received from government milk scheme in Nanded town. Interlink. Res. Ana. 1, 32-53.

Santos, P.M., Pereira-Filho, E.R., RodriguezSaona, L.E., 2013. Application of hand-held and portable infrared spectrometers in bovine milk analysis. J Agric Food Chem 61, 1205-1211.

Skaug, M.A., 1999. Analysis of Norwegian milk and infant formulas for ochratoxin A. Food Addit Contam 16, 75-78.

UOL, 2014. Operação desmonta esquema de empresas que adulteravam leite noSul. Available in $<\underline{\text { http://noticias.uol.com.br/cotidiano/ultima }}$ s-noticias/2013/05/08/operacao-desmontaesquema-de-empresas-que-fraudavam-leiteno-sul. htm>. Accessed in June 2014. 